\title{
In situ high-temperature behaviour of fluor-elbaite: breakdown conditions and products
}

\author{
Beatrice Celata ${ }^{1}$ (C) Paolo Ballirano ${ }^{1} \cdot$ Giovanni B. Andreozzi ${ }^{1} \cdot$ Ferdinando Bosi $^{1}$
}

Received: 31 March 2021 / Accepted: 19 May 2021 / Published online: 8 June 2021

(c) The Author(s) 2021

\begin{abstract}
The thermal behaviour of a fluor-elbaite from Minas Gerais (Brazil) was investigated at room pressure through in situ hightemperature X-ray powder diffraction (HT-XRPD), until the breakdown conditions were reached. The variations of fluorelbaite structural parameters (unit-cell parameters and mean bond distances) were monitored together with site occupancies, and two main internal reactions were identified: the thermally-induced Fe oxidation process counterbalanced by $(\mathrm{OH})^{-}$deprotonation, which starts at $500{ }^{\circ} \mathrm{C}(773 \mathrm{~K})$, followed by a partial intracrystalline $\mathrm{Fe}-\mathrm{Al}$ exchange between the octahedrallycoordinated $Y$ and $Z$ sites. The fluor-elbaite breakdown reaction occurs between $850{ }^{\circ} \mathrm{C}(1123 \mathrm{~K})$ and $900{ }^{\circ} \mathrm{C}(1173 \mathrm{~K})$. The breakdown products were identified at room temperature by XRPD and the breakdown reaction can be described by the following reaction: tourmaline $\rightarrow \mathrm{B}$-bearing mullite + hematite + spinel $+\mathrm{B}$-poor $\left(\mathrm{Na}, \mathrm{Li}, \mathrm{H}_{2} \mathrm{O}\right)$-bearing glass. Boromullite itself was not observed in the final heating products, and the B-bearing mullite from the breakdown reaction exhibited unitcell parameters $a=7.5382(2) \AA, b=7.6749(2) \AA, c=2.8385(1) \AA, V=164.22(1) \AA^{3}$ (space group Pbam) consistent with an approximate $\mathrm{Al}_{8.5} \mathrm{~B}_{1.5} \mathrm{Si}_{2} \mathrm{O}_{19}$ composition.
\end{abstract}

Keywords Fluor-elbaite · HT-XRPD · Thermal expansion · Iron oxidation · Deprotonation · Intracrystalline cations exchange $\cdot$ Structural breakdown

\section{Introduction}

Tourmaline is one of the most fascinating and colourful accessory mineral occurring in a variety of geological environments, from diagenetic stages to granulite facies grade (e.g., Henry and Dutrow 1996; Dutrow and Henry 2011; Bosi et al. 2018a, 2019a; Andreozzi et al. 2020).

Tourmaline is a cyclosilicate rich in B with a very complex composition represented by the general chemical formula: $\mathrm{XY}_{3} \mathrm{Z}_{6} \mathrm{~T}_{6} \mathrm{O}_{18}\left(\mathrm{BO}_{3}\right)_{3} \mathrm{~V}_{3} \mathrm{~W}$, where $\mathrm{X}=\mathrm{Na}^{+}, \mathrm{K}^{+}, \mathrm{Ca}^{2+}$, $\square\left(=\right.$ vacancy); $\mathrm{Y}=\mathrm{Al}^{3+}, \mathrm{Fe}^{3+}, \mathrm{Cr}^{3+}, \mathrm{V}^{3+}, \mathrm{Mg}^{2+}, \mathrm{Fe}^{2+}$, $\mathrm{Mn}^{2+}, \mathrm{Li}^{+} ; \mathrm{Z}=\mathrm{Al}^{3+}, \mathrm{Fe}^{3+}, \mathrm{Cr}^{3+}, \mathrm{V}^{3+}, \mathrm{Mg}^{2+}, \mathrm{Fe}^{2+} ; \mathrm{T}=\mathrm{Si}^{4+}$, $\mathrm{Al}^{3+}, \mathrm{B}^{3+} ; \mathrm{B}=\mathrm{B}^{3+} ; \mathrm{V}=(\mathrm{OH})^{-}, \mathrm{O}^{2-} ; \mathrm{W}=(\mathrm{OH})^{-}, \mathrm{F}^{-}, \mathrm{O}^{2-}$. Note that the non-italicized letters $\mathrm{X}, \mathrm{Y}, \mathrm{Z}, \mathrm{T}$ and $\mathrm{B}$ represent groups of cations at the ${ }^{[9]} X,{ }^{[6]} Y,{ }^{[6]} Z,{ }^{[4]} T$ and ${ }^{[3]} B$

Beatrice Celata

beatrice.celata@uniroma1.it

Paolo Ballirano

paolo.ballirano@uniroma1.it

1 Dipartimento di Scienze della Terra, Sapienza Università di Roma, Piazzale A. Moro 5, 00185 Rome, Italy crystallographic sites (italicized letters) and the letters $\mathrm{V}$ and $\mathrm{W}$ represent groups of anions accommodated at the [3]-coordinated $\mathrm{O} 3$ and $\mathrm{O} 1$ crystallographic sites, respectively. Tourmaline-supergroup minerals are currently classified into three groups, vacant, alkali and calcic, based on the $X$-site occupancy (Henry et al. 2011). A further level of classification into subgroups is based on the charge arrangements at the $Y$ and $Z$ sites. Tourmalines are also distinguished by the dominant anion at the $\mathrm{W}$ position of the general formula into hydroxy-, fluor- and oxy-species.

Tourmaline gained more and more interest along the years surely because of its remarkable power to carry a lot of information about its genetic conditions (e.g., Federico et al. 1998; Dutrow and Henry 2011). However, tourmaline relevance stands even more in its role of boron and water carrier from the crust deep down the mantle and the implications it may have (Henry and Dutrow 1996; Ota et al. 2008a, b; Shimizu and Ogasawara 2013; Lussier et al. 2016). In fact, the boron and water released because of tourmaline breakdown reduce both the solidus temperature of the hosting rock and the viscosity of any associated melt (Pichavant 1981; Dingwell et al. 1992). Remarkably, how 
the breakdown conditions are reached in terms of structural variations has never been investigated so far, as well as it remains unclear when the deprotonation process exactly starts, i.e., if "water" is actually released throughout the breakdown process or way before the structural collapse as suggested, for example, by the studies of Filip et al. (2012) and Bosi et al. (2018b).

The present work aims at investigating the thermal behaviour of the fluor-elbaite, ideally $\mathrm{Na}\left(\mathrm{Li}_{1.5} \mathrm{Al}_{1.5}\right) \mathrm{Al}_{6}\left(\mathrm{Si}_{6} \mathrm{O}_{18}\right)$ $\left(\mathrm{BO}_{3}\right)_{3}(\mathrm{OH})_{3} \mathrm{~F}$ (Bosi et al. 2013) at room pressure. A Febearing deep green fluor-elbaite sample from the Cruzeiro pegmatite (Minas Gerais, Brazil), previously fully characterized by Bosi et al. (2019b) with the formula:
Table 1 Miscellaneous data of the data collection and Rietveld refinements of the fluor-elbaite studied

\begin{tabular}{ll}
\hline $2 \theta$ range $\left({ }^{\circ}\right)$ & $7-145$ \\
$2 \theta$ step-size $\left({ }^{\circ}\right)$ & 0.021798 \\
Counting time (s) & 3 \\
$T_{\max }\left({ }^{\circ} \mathrm{C}\right)$ & 850 \\
$T$ steps $\left({ }^{\circ} \mathrm{C}\right)$ & 50 \\
$\mathrm{Rp}(\%)$ & $1.772-2.275$ \\
$\mathrm{Rwp}(\%)$ & $2.392-3.312$ \\
$R_{\text {Bragg }}(\%)$ & $0.907-1.303$ \\
DWd & $0.801-1.363$ \\
$X^{2}$ & $1.767-2.509$ \\
\hline Definition of the statistical indi- \\
cators, from Young (1993)
\end{tabular}

$\mathrm{X}\left(\mathrm{Na}_{0.79} \square_{0.18} \mathrm{Ca}_{0.02} \mathrm{~K}_{0.01}\right)_{\Sigma 1.00}{ }^{\mathrm{Y}}\left(\mathrm{Al}_{0.95} \mathrm{Fe}_{0.94}^{2+} \mathrm{Li}_{0.86} \mathrm{Mn}_{0.18}^{2+} \mathrm{Zn}_{0.11} \mathrm{Ti}_{0.01}\right)_{\Sigma 3.05}$
${ }^{\mathrm{Z}} \mathrm{Al}_{6}{ }^{\mathrm{T}}\left(\mathrm{Si}_{5.99} \mathrm{Al}_{0.01}\right)_{\Sigma 6.00} \mathrm{~B}_{2.98} \mathrm{O}_{27}{ }^{\mathrm{V}}(\mathrm{OH})_{3}{ }^{\mathrm{W}}\left[(\mathrm{OH})_{0.43} \mathrm{~F}_{0.58}\right]_{\Sigma 1.01}$

was studied by in situ high-temperature X-ray powder diffraction (HT-XRPD) up to the structural breakdown.

\section{Experimental}

The fluor-elbaite crystal fragment was gently grinded in ethanol, in an agate mortar; the powder was then loaded in a $0.7 \mathrm{~mm}$ diameter $\mathrm{SiO}_{2}$-glass capillary kept open at one side. The capillary was fixed to a hollow corundum tube using a HT cement and mounted and aligned on a goniometer head. The capillary was inserted into the heating chamber for capillaries, developed by MRI and Bruker AXS, that is placed along the beam path of the diffractometer. Characteristics and thermal calibration procedure of the chamber are reported in Ballirano and Melis (2007).

In situ HT-XRPD data were measured on a Bruker AXS D8 Advance that operates in $\theta / \theta$ geometry in transmission mode. The instrument is fitted with focussing multilayer graded (Göbel) mirrors placed along the incident beam and Soller slits on both the incident $\left(2.3^{\circ}\right.$ opening angle $)$ and diffracted (radial) beams. The data were collected using a position sensitive detector (PSD) VÅntec-1 operating at an opening angle of $6^{\circ} 2 \theta$. Details of the data collection are reported in Table 1.

At the end of the heating run, the powder was cooled back at room temperature (RT) within the chamber, removed from the capillary, re-homogenised and charged in a new borosilicate-glass capillary. This procedure was followed to reduce the possible effect of textured recrystallization at the walls of the capillary. As a side effect, re-homogenisation involved also powder lying at the coldest extremity of the capillary where $T$, owing to thermal gradients, was significantly smaller than that reached in the analysed part of the sample. A measurement of this sample was performed outside the chamber.
Data evaluation was performed by the Rietveld method using Topas 6 (Bruker 2016). The Fundamental Parameters Approach (FPA: Cheary and Coelho 1992) was used to describe the peak shape. The equation of Sabine et al. (1998) for a cylindrical sample was applied for absorption correction using the approach of Ballirano and Maras (2006) for handling the correlation existing between displacement parameters and absorption. In particular, isotropic displacement parameters were constrained as follow: $\mathrm{B}_{Y}=\mathrm{B}_{Z}=\mathrm{B}_{B}=\mathrm{B}_{T}$; $\mathrm{B}_{\mathrm{O} 2}=\mathrm{B}_{\mathrm{O} 3}=\mathrm{B}_{\mathrm{O} 4}=\mathrm{B}_{\mathrm{O} 5}=\mathrm{B}_{\mathrm{O} 6}=\mathrm{B}_{\mathrm{O} 7}=\mathrm{B}_{\mathrm{O} 8}$. Preferred orientation effects were corrected using spherical harmonics (8th-order, nine refinable parameters) by selecting the number of appropriate terms following the procedure described by Ballirano (2003). As expected for data collected in transmission-mode on capillaries, the coefficients refined to small values. Starting structural data were those of Bosi et al. (2019b) and each refined structure at a given non-ambient $T$ was used as input for the subsequent $T$. EoSFit7-GUI (Gonzalez-Platas et al. 2016) was used to analyse the dependence of the unit-cell parameters from $T$ employing the equation of Berman (1988) for fitting the data. This equation has the advantage to permit accommodation of non-linear thermal expansion. It is expressed as $X_{T}=X_{0}\left[1+a_{0}\left(T-T_{r e f}\right)+\frac{1}{2} a_{1}\left(T-T_{r e f}\right)^{2}\right]$ with $X=V, a$, $c$. Miscellaneous information regarding the refinements is listed in Table 1 and a representative example of Rietveld plots is shown in Fig. 1. CIF files of the fluor-elbaite structure refined at the various $T$ are given in Online Resource.

\section{Results and discussion}

\section{Breakdown products of F-elbaite}

The first evidence of fluor-elbaite structural breakdown was observed at $850{ }^{\circ} \mathrm{C}$ owing to the occurrence of very weak 


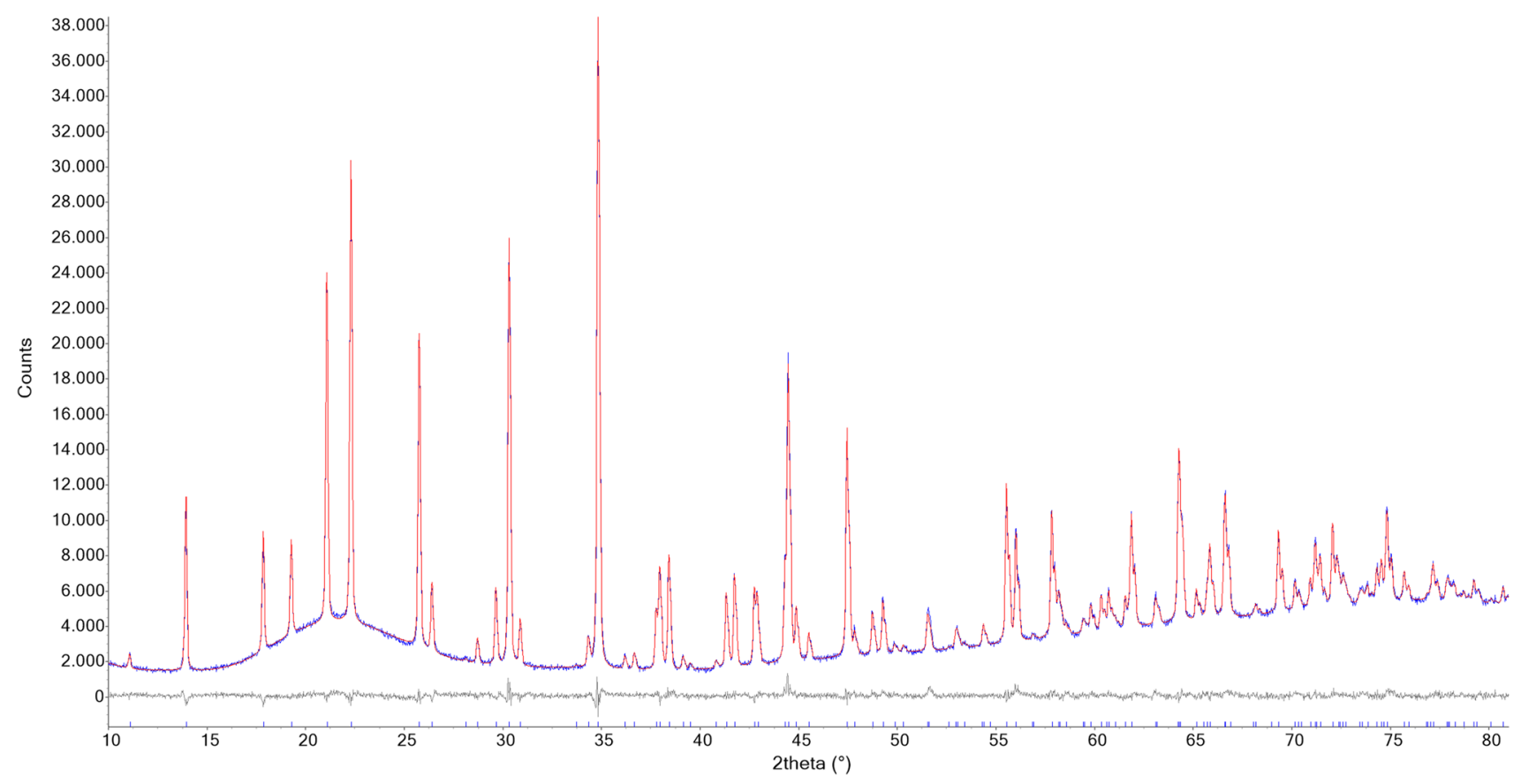

Fig. 1 Representative example of the Rietveld plots of the diffraction pattern collected at $423 \mathrm{~K}$. Blue: experimental; red: calculated; grey: difference; vertical bars: position of calculated Bragg reflections of the fluor-elbaite studied

diffraction reflections assigned to a mullite-like phase. The breakdown was completed at the $T$ of $900{ }^{\circ} \mathrm{C}$. The quantitative phase analysis (QPA) of the sample cooled down at RT (Fig. 2) indicates the occurrence of prevailing mullite-like phase plus minor hematite and traces of spinel as breakdown products. Furthermore, the increased intensity of the broad band centred at ca. $22^{\circ} 2 \theta$, in addition to the contribution of the capillary glass, also reveals the occurrence of some

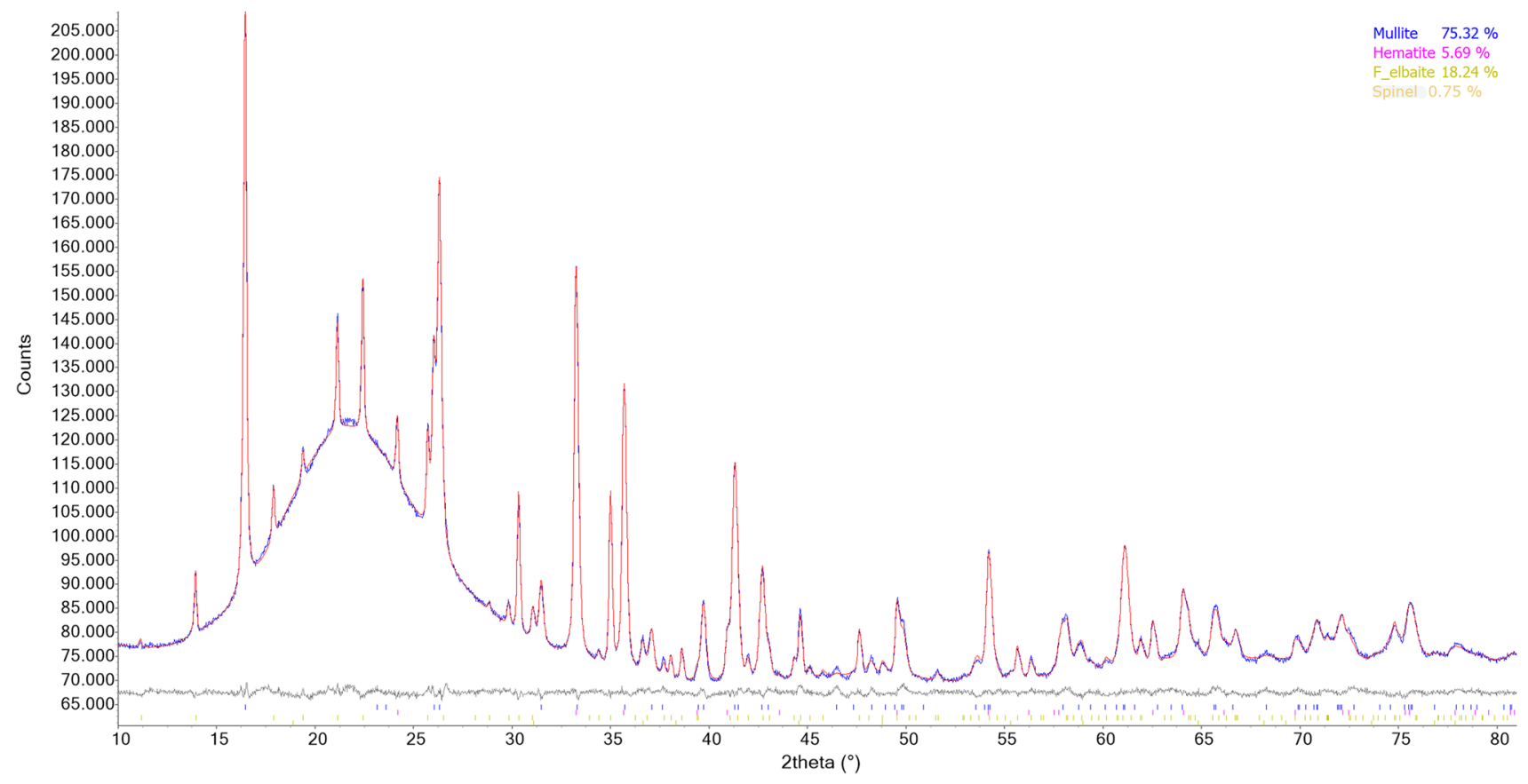

Fig. 2 Magnified $10-80^{\circ} 2 \theta$ view of the Rietveld plots of the products of breakdown of the fluor-elbaite studied. Blue: experimental; red: calculated; grey: difference; vertical bars: position of calculated
Bragg reflections of (from above to below) mullite, hematite, fluorelbaite (unreacted) and spinel 
amorphous material, likely being the cooling product of a Si-rich hydrous fluid derived from the tourmaline breakdown. Relicts of unreacted fluor-elbaite were caused by the re-homogenisation of the powder (see "Experimental").

Refined unit-cell parameters of the mullite-like phase, in the space group Pbam, were $a=7.5382(2) \AA$, $b=7.6749$ (2) $\AA, c=2.8385(1) \AA, \mathrm{V}=164.22(1) \AA^{3}$ and are consistent with those of B-mullites (Lührs et al. 2014). An estimation of the B content was carried out using the regression equations proposed by Lührs et al. (2014), based on the $b$ - and $c$-parameters $\left(b=-0.0030(2) \times \mathrm{B}_{2} \mathrm{O}_{3}\right.$ mol.\% + 7.6921(8): $R^{2}=0.99 ; c=-0.0041(2) \times \mathrm{B}_{2} \mathrm{O}_{3}$ mol.\%+2.8876(19): $\left.R^{2}=0.96\right)$. The results point out to a content of ca. 6-12 mol.\% $\mathrm{B}_{2} \mathrm{O}_{3}$, corresponding to the $\mathrm{Al}_{8} \mathrm{~B}_{2} \mathrm{Si}_{2} \mathrm{O}_{19}-\mathrm{Al}_{9} \mathrm{BSi}_{2} \mathrm{O}_{19}$ compositional range. It is worth noting that the mineral boromullite, space group being $C m c 2_{1}, a=5.7168(19) \AA, b=15.023(5) \AA, c=7.675(3) \AA$, $V=659.2(7) \AA^{3}$ with composition $\mathrm{Al}_{9} \mathrm{BSi}_{2} \mathrm{O}_{19}$, has been described by Buick et al. (2008). However, attempts to use this superstructure as starting structure for the present B-mullite (using a $4 \times$ larger supercell $a^{\prime}=2 c=5.6770(1) \AA$, $b^{\prime}=2 a=15.0763(4) \AA$ and $c^{\prime}=b=7.6749$ (2) $\AA$, obtained by the transformation matrix $002 / 200 / 010$ ) produced relatively strong unobserved reflections, clearly indicating the inability of the model to fit the data. Moreover, Werding and Schreyer (1992) reported the orthorhombic unit-cell parameters $a=5.681(2) \AA, b=15.014(5) \AA, c=7.671(4) \AA$, $V=654.3(3) \AA^{3}$ for a sample of $\mathrm{Al}_{8} \mathrm{~B}_{2} \mathrm{Si}_{2} \mathrm{O}_{19}$ composition. It is interesting to notice that $V$ ' of the present sample, calculated from the $4 \times$ larger supercell, is equal to 656.88 (3) $\AA^{3}$, which is a value located exactly halfway between those of $\mathrm{Al}_{8} \mathrm{~B}_{2} \mathrm{Si}_{2} \mathrm{O}_{19}$ and $\mathrm{Al}_{9} \mathrm{BSi}_{2} \mathrm{O}_{19}$.

Finally, the recently discovered $(\mathrm{Li}, \mathrm{Be})$-bearing borosilicate mineral vránaite, ideally $\mathrm{Al}_{16} \mathrm{~B}_{4} \mathrm{Si}_{4} \mathrm{O}_{38}$ (Novák et al. 2015; Cempírek et al. 2016), was also considered since it was found as a breakdown product of spodumene in the elbaite-subtype Manjaka granitic pegmatite (Novák et al. 2015), and its space group $I 2 / m$ can be derived from the orthorhombic supergroup Pbam (Fischer and Schneider 2008) to which our structural refined data refer to. Vránaite cell parameters are $a=10.383(1) \AA, b=5.668(1) \AA$, $c=10.823(1) \AA, \beta=90.11(1)^{\circ}, V=637.0(1) \AA^{3}$. However, similarly to boromullite, attempts to fit the XRPD data using the structural parameters of vránaite produced significantly worse agreement indices than those obtained for B-mullite. In particular, the markedly different cell parameters resulted in a unit cell volume of ca. $657 \AA^{3}$, significantly larger than that reported for vránaite.

Thus, a mullite-type phase of approximate $\mathrm{Al}_{8.5} \mathrm{~B}_{1.5} \mathrm{Si}_{2} \mathrm{O}_{19}$ composition may represent the breakdown crystalline phase incorporating $\mathrm{B}$.

Because the $\mathrm{B} / \mathrm{Si}$ ratio observed in pristine fluor-elbaite was $1: 2$ and that of the present recrystallized B-mullite is approximately $1.5: 2$, it is most likely that the Si-rich amorphous component retrieved at the end of the breakdown process is very poor in B.

Moreover, considering that pristine fluor-elbaite is a hydrated phase containing a definite amount of $\mathrm{Na}$ and $\mathrm{Li}$ and that no hydrated Na- and Li-bearing breakdown products are observed, it is very likely that the silicatic amorphous component may also contain $\mathrm{Na}$ and $\mathrm{Li}$ and $\mathrm{H}_{2} \mathrm{O}$, as commonly used in experimental investigation of tourmaline formation (e.g., Orlando et al. 2017).

The observed hematite accommodates the oxidised $\mathrm{Fe}$ and spinel probably accommodates the remaining $\mathrm{Fe}(\mathrm{Mn})$ and $\mathrm{Al}$ of the pristine fluor-elbaite.

\section{Thermal expansion and HT structure modifications}

Variation of unit-cell parameter values for the fluor-elbaite at each $T$ is reported in Table 2, and the relative expansion of the same parameters as a function of $T$ is shown in Fig. 3.

A non-linear thermal expansion is observed, with the occurrence of several discontinuities. The $a$-parameter deviates from the regularly increasing trend around $500{ }^{\circ} \mathrm{C}$ and shows a flattening, suddenly followed by a marked decrease that ends at $700{ }^{\circ} \mathrm{C}$; above this $T$, the $a$-parameter increases again with approximately the same rate observed below $500{ }^{\circ} \mathrm{C}$. The $c$-parameter experiences a different behaviour as the discontinuity occurs at a higher $T\left(650{ }^{\circ} \mathrm{C}\right)$ and consists in an increased expansion rate. These opposite behaviours suggest the onset of two different structural

Table 2 Refined cell parameters at the various temperatures of the fluor-elbaite studied

\begin{tabular}{llll}
\hline$T\left({ }^{\circ} \mathrm{C}\right)$ & $a(\AA)$ & $c(\AA)$ & Volume $\left(\AA^{3}\right)$ \\
\hline 30 & $15.9187(1)$ & $7.1283(1)$ & $1564.35(2)$ \\
50 & $15.9199(1)$ & $7.1297(1)$ & $1564.87(3)$ \\
100 & $15.9228(1)$ & $7.1328(1)$ & $1566.15(2)$ \\
150 & $15.9262(1)$ & $7.1362(1)$ & $1567.56(3)$ \\
200 & $15.9298(1)$ & $7.1398(1)$ & $1569.04(3)$ \\
250 & $15.9345(1)$ & $7.1441(1)$ & $1570.92(3)$ \\
300 & $15.9387(1)$ & $7.1481(1)$ & $1572.64(3)$ \\
350 & $15.9435(1)$ & 7.1527() & $1574.59(3)$ \\
400 & $15.9475(1)$ & $7.1572(1)$ & $1576.37(3)$ \\
450 & $15.9504(1)$ & $7.1618(1)$ & $1577.97(3)$ \\
500 & $15.9489(2)$ & $7.1662(1)$ & $1578.63(5)$ \\
550 & $15.9361(3)$ & $7.1701(1)$ & $1576.94(7)$ \\
600 & $15.9193(3)$ & $7.1748(1)$ & $1574.48(6)$ \\
650 & $15.9087(2)$ & $7.1842(1)$ & $1574.63(4)$ \\
700 & $15.9077(1)$ & $7.1965(1)$ & $1577.14(3)$ \\
750 & $15.9097(1)$ & $7.2040(1)$ & $1579.16(3)$ \\
800 & $15.9134(1)$ & $7.2099(1)$ & $1581.20(3)$ \\
850 & $15.9138(2)$ & $7.2181(1)$ & $1583.07(5)$ \\
\hline
\end{tabular}




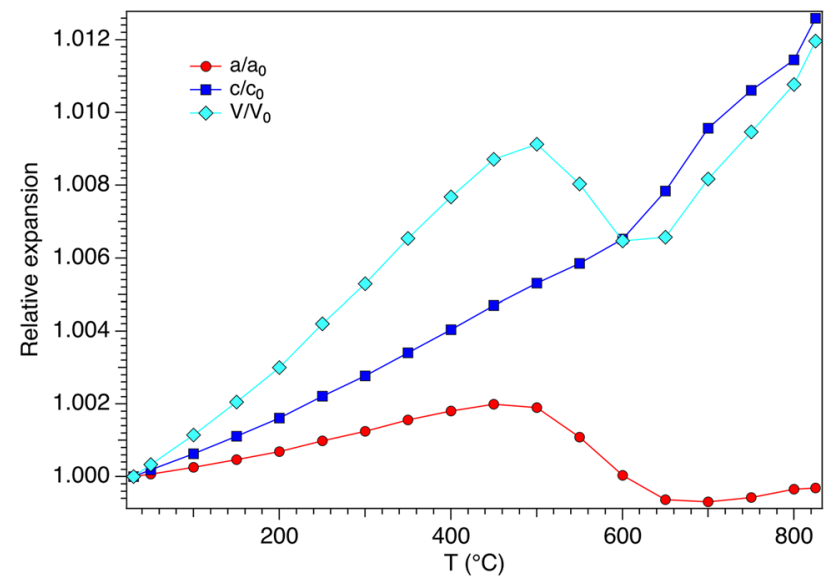

Fig. 3 Change of normalized unit-cell parameters with $T$ for the fluorelbaite studied

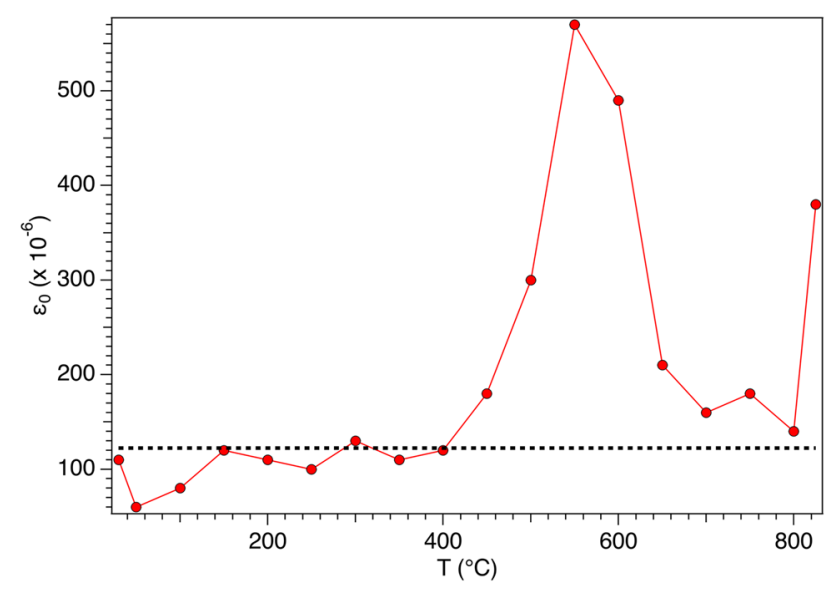

Fig. 4 Variation of $\varepsilon_{0}$ microstrain with $T$ for the fluor-elbaite studied. The dotted horizontal line, corresponding to the $\varepsilon_{0}$ value at $R T$, is drawn as a guide for the eye

processes and are reflected by the net volume contraction occurring in the $500-600{ }^{\circ} \mathrm{C}$ thermal range, followed by the restart of volume increase after $650{ }^{\circ} \mathrm{C}$.

It is worth noting that $\varepsilon_{0}$ microstrain (lattice strain), defined as $\beta_{i}=4 \varepsilon_{0} \tan \theta$, where $\beta_{i}$ is the integral breadth of the $j$ th reflection, refined as a part of the profile shape optimization (Ballirano and Sadun 2009), shows a significant increase in the same thermal range $\left(450-700{ }^{\circ} \mathrm{C}\right)$ where the unit-cell parameters deviate from the regular trends (450-700 ${ }^{\circ}$ C, Fig. 4).
Table 3 Relevant parameters of the fitting procedure by the Berman equation of the unit-cell parameters vs. $T$ data of the fluor-elbaite studied

\begin{tabular}{lclll}
\hline & $V_{0}, a_{0}, c_{0}\left(\AA^{3}, \AA, \AA\right)$ & $a_{0}\left(\times 10^{-5} \mathrm{~K}^{-1}\right)$ & $a_{1}\left(\times 10^{-9} \mathrm{~K}^{-2}\right)$ & $X^{2}{ }_{w}$ \\
\hline$V\left(\AA^{3}\right)$ & $1564.38(6)$ & $1.59(5)$ & $2.6(3)$ & 8.64 \\
$a(\AA)$ & $15.9188(2)$ & $0.371(17)$ & $0.66(10)$ & 6.26 \\
$c(\AA)$ & $7.1284(1)$ & $0.849(16)$ & $1.32(9)$ & 3.19 \\
\hline
\end{tabular}

Temperature of reference $=30^{\circ} \mathrm{C}(303 \mathrm{~K})$

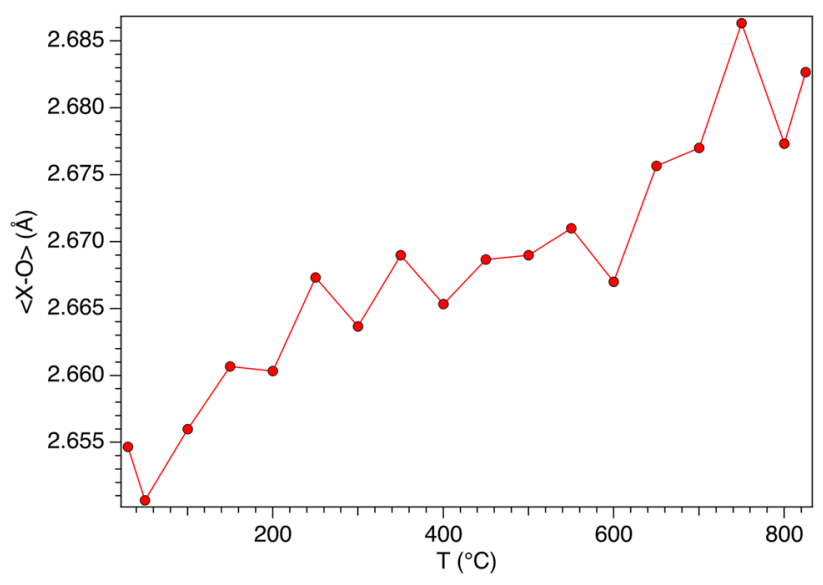

Fig. 5 Variation of $\langle X-\mathrm{O}\rangle$ bond distances with $T$ for the fluor-elbaite studied

The variation of the unit-cell parameters with $T$ was modelled up to $400{ }^{\circ} \mathrm{C}$, i.e., before the onset of structural modifications, using the Berman equation (Berman 1988). Table 3 reports the relevant parameters of the fitting procedure. The data indicate that the $c$-parameter is softer than the $a$-parameter against $T$.

As far as the structural modifications are referred to, the $<X-\mathrm{O}>$ mean bond distance shows an irregular increase with $T$ (Fig. 5). In spite of a marked enlargement tentatively exhibited at higher temperature, the possibility of Na release and a consequent increase of the $X$-site vacant component, which might enlarge $\langle X-\mathrm{O}\rangle$ (Bosi et al. 2005), is not fully supported by experimental data. Moreover, the modifications observed by Bosi et al. (2019b) on a single-crystal fragment of the same fluor-elbaite studied in this work, heated in air at the $T$ of $800{ }^{\circ} \mathrm{C}$ and studied at RT by single crystal X-ray diffraction, confirmed that $\mathrm{Na}$ was not released after heating, as reported in their empirical formula,

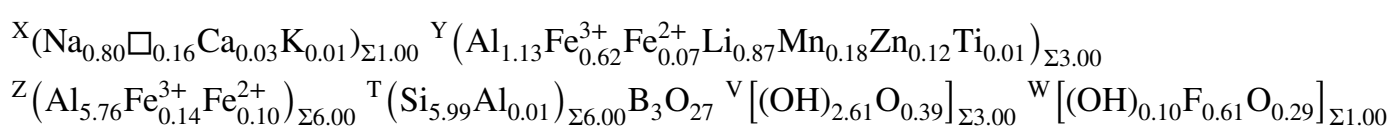




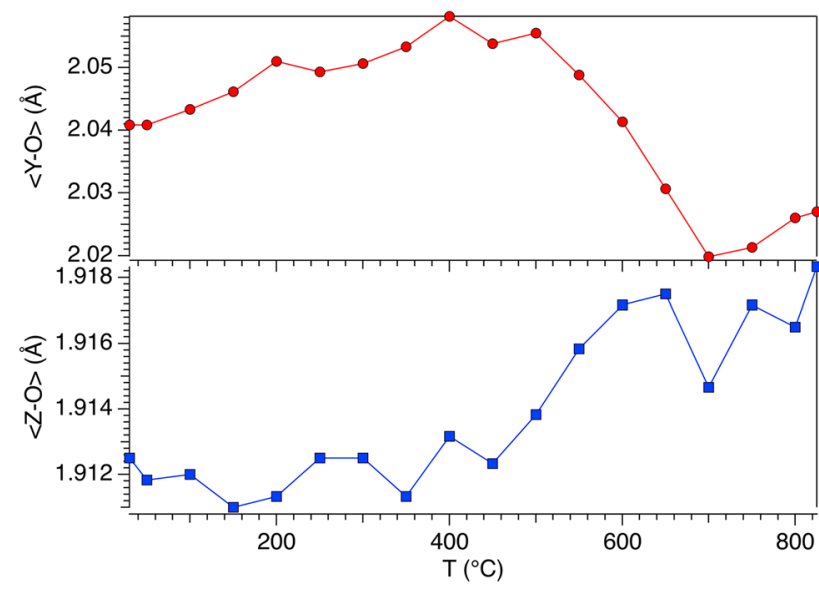

Fig. 6 Dependence of $\langle Y-\mathrm{O}\rangle$ (upper panel) and $\langle Z-\mathrm{O}\rangle$ (lower panel) bond distances from $T$ for the fluor-elbaite studied

which has the same Na content of the pristine fluor-elbaite.

The dependence of $\langle Y-\mathrm{O}\rangle$ and $\langle Z-\mathrm{O}\rangle$ bond distances from $T$ displays a different behaviour (Fig. 6). In particular, the $\langle Y-\mathrm{O}>$ bond distance regularly increases from 2.048 to $2.064 \AA$ due to thermal expansion when $T$ increases from $\mathrm{R} T$ to $500{ }^{\circ} \mathrm{C}$, then contracts significantly to $2.027 \AA$ in the range $500-700{ }^{\circ} \mathrm{C}$ and slightly increases again up to the breakdown $T$ of $850{ }^{\circ} \mathrm{C}$. Conversely, the $<Z-\mathrm{O}>$ bond distance regularly increases up to the breakdown, although an increment of the expansion is observed at $500{ }^{\circ} \mathrm{C}$.

The $\langle Y-\mathrm{O}\rangle$ and $\langle Z-\mathrm{O}\rangle$ modifications observed in situ correlate nicely with the structural modifications observed by Bosi et al. (2019b) on the same fluor-elbaite as a result of their thermal treatment followed by ex situ study. In fact, these authors observed a marked $<Y-\mathrm{O}\rangle$ shrinking together with limited $<Z-\mathrm{O}>$ enlargement which was interpreted as the occurrence of $\mathrm{Fe}^{2+}$ oxidation to $\mathrm{Fe}^{3+}$, counterbalanced by the deprotonation of $(\mathrm{OH})^{-}$groups and described by the reaction $\left(\mathrm{Fe}^{2+}\right)+(\mathrm{OH})^{-} \rightarrow\left(\mathrm{Fe}^{3+}\right)+\left(\mathrm{O}^{2-}\right)+1 / 2 \mathrm{H}_{2}(\mathrm{~g})$. It is worth noting that the whole $\mathrm{Fe}$ content of the starting sample of fluor-elbaite was $\mathrm{Fe}^{2+}$; therefore, given that the empirical mean ionic radius of ${ }^{[6]} \mathrm{Fe}^{3+}$ is smaller than that of ${ }^{[6]} \mathrm{Fe}^{2+}$ [0.675(15) A vs. 0.776(1) $⿱$, respectively, Bosi (2018)], we may conclude that in fluor-elbaite the Fe oxidation starts at $500{ }^{\circ} \mathrm{C}$ and the heating is definitely the driving force that also rules the associated deprotonation (required to restore the overall charge balance even under reducing conditions, see Bosi et al. 2019b for details).

To explain the observed variation of Fe occupancy at the $Y$ and $Z$ sites with $T$ (Fig. 7), the onset of an intracrystalline exchange process after $650{ }^{\circ} \mathrm{C}$ has to be hypothesized. After $\mathrm{Fe}^{2+}$ oxidation to $\mathrm{Fe}^{3+}$, some amounts of $\mathrm{Fe}$ migrate from the larger $\mathrm{YO}_{6}$ polyhedron to the adjacent smaller ${ }^{Z} \mathrm{AlO}_{6}$ polyhedron, which in turn moves $\mathrm{Al}$ to the $Y$ site. This process can be described by the intracrystalline order-disorder reaction

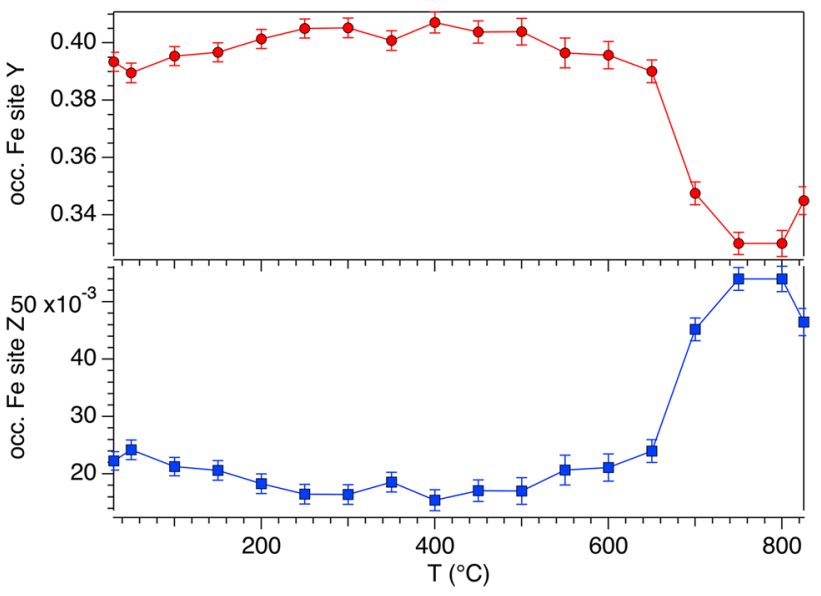

Fig. 7 Evolution with $T$ of the Fe (+Mn) occupancy at the $Y$ and $Z$ sites for the fluor-elbaite studied

${ }^{Y} \mathrm{Fe}+{ }^{Z} \mathrm{Al} \rightarrow{ }^{Z} \mathrm{Fe}+{ }^{Y} \mathrm{Al}$, which was observed on thermallytreated tourmaline single-crystals by Bosi et al. (2019b) for fluor-elbaite, Bosi et al. (2018b) for lucchesiite and Filip et al. (2012) for schorl. In the studied fluor-elbaite, this process probably ends at $750{ }^{\circ} \mathrm{C}$, when the $\mathrm{Fe}$ is reasonably supposed to be fully oxidized (Fig. 7).

Both the oxidation reaction of $\mathrm{Fe}^{2+}$ to $\mathrm{Fe}^{3+}$ at the $Y$ site and the above reported intracrystalline order-disorder reaction contribute to explain the observed dependence of $\langle Y-\mathrm{O}\rangle$ and $\langle Z$-O $\rangle$ from $T$ (Fig. 6). In fact, the abrupt contraction of $\langle Y-\mathrm{O}\rangle$ is consistent with the combination of the two reactions, which leads to the reduction of the aggregate size of the constituent cation $\left\langle{ }^{\mathrm{Y}} \mathrm{r}\right\rangle$. As above mentioned, the empirical mean ionic radius of ${ }^{[6]} \mathrm{Fe}^{3+}$ is smaller than that of ${ }^{[6]} \mathrm{Fe}^{2+}[0.675(15) \AA$ vs. $0.776(1) \AA$, respectively], and the empirical mean ionic radius of ${ }^{[6]} \mathrm{Al}$ is much smaller than that ${ }^{[6]} \mathrm{Fe}^{3+}[0.547(3)$ $\AA$ vs. 0.675(15) $\AA$, Bosi (2018)]. The minor expansion of $\langle Z-O=$ in the same thermal range is consistent with the smaller increase of the aggregate size of the constituent cation $<{ }^{\mathrm{Z}}>$ than $<{ }^{\mathrm{Y}_{\mathrm{r}}}>$ caused by double multiplicity of the $\mathrm{Z}$ site with respect to $Y$. A similar behaviour was observed for both Fe-dominant/rich tourmalines (e.g., Filip et al. 2012; Bosi et al. 2018b, 2019b) and Fe-bearing amphiboles (Oberti et al. 2018; Pacella et al. 2020; Ballirano and Pacella 2020).

\section{Conclusions}

The thermal behaviour of fluor-elbaite was investigated up to structural breakdown through in situ HT-XRPD.

Well before the breakdown, heating the fluor-elbaite at $500{ }^{\circ} \mathrm{C}(773 \mathrm{~K})$ in air was enough to set the $\mathrm{Fe}$ oxidation out, counterbalanced by the deprotonation reaction: 
$\left(\mathrm{Fe}^{2+}\right)+(\mathrm{OH})^{-} \rightarrow\left(\mathrm{Fe}^{3+}\right)+\left(\mathrm{O}^{2-}\right)+1 / 2 \mathrm{H}_{2}(\mathrm{~g})$. Since the capillary acted as a closed system, the early formation of an aqueous fluid may be envisaged at this stage. At a higher temperature, quantified around $650{ }^{\circ} \mathrm{C}(923 \mathrm{~K}), \mathrm{Fe}$ starts to migrate from the $Y$ to the $Z$ sites, according to the intracrystalline order-disorder reaction ${ }^{Y} \mathrm{Fe}+{ }^{Z} \mathrm{Al} \rightarrow{ }^{Z} \mathrm{Fe}+{ }^{Y} \mathrm{Al}$.

Fluor-elbaite structural breakdown starts at $850{ }^{\circ} \mathrm{C}$ (1123 K), owing to the first occurrence of a mullite-like phase in the decomposition products, and the process is complete at $900{ }^{\circ} \mathrm{C}(1173 \mathrm{~K})$. Tourmaline breakdown products have been identified as B-mullite (for the most part), hematite, spinel and a silicatic B-poor $\left(\mathrm{Na}, \mathrm{Li}, \mathrm{H}_{2} \mathrm{O}\right)$-bearing glass.

Supplementary Information The online version contains supplementary material available at https://doi.org/10.1007/s00269-021-01147-5.

Acknowledgements Sapienza University of Rome grant (Prog. Università 2018 to $\mathrm{F}$. Bosi) is gratefully acknowledged. We sincerely thank Jan Cempírek for his brilliant advices that significantly improved this work and Andreas Ertl for the warm-hearted and careful revision of this manuscript that definitely powered its scientific impact.

Funding Open access funding provided by Università degli Studi di Roma La Sapienza within the CRUI-CARE Agreement.

\section{Declarations}

Conflict of interest The authors declare no conflict of interest.

Open Access This article is licensed under a Creative Commons Attribution 4.0 International License, which permits use, sharing, adaptation, distribution and reproduction in any medium or format, as long as you give appropriate credit to the original author(s) and the source, provide a link to the Creative Commons licence, and indicate if changes were made. The images or other third party material in this article are included in the article's Creative Commons licence, unless indicated otherwise in a credit line to the material. If material is not included in the article's Creative Commons licence and your intended use is not permitted by statutory regulation or exceeds the permitted use, you will need to obtain permission directly from the copyright holder. To view a copy of this licence, visit http://creativecommons.org/licenses/by/4.0/.

\section{References}

Andreozzi GB, Bosi F, Celata B, Capizzi LS, Stagno V, BeckettBrown CE (2020) Crystal-chemical behavior of $\mathrm{Fe}^{2+}$ in tourmaline dictated by structural stability: insights from a schorl with formula $\mathrm{Na}^{\mathrm{Y}}\left(\mathrm{Fe}^{2+}{ }_{2} \mathrm{Al}\right)^{\mathrm{Z}}\left(\mathrm{Al}_{5} \mathrm{Fe}^{2+}\right)\left(\mathrm{Si}_{6} \mathrm{O}_{18}\right)\left(\mathrm{BO}_{3}\right)_{3}(\mathrm{OH})_{3}(\mathrm{OH}, \mathrm{F})$ from Seagull batholith (Yukon Territory, Canada). Phys Chem Miner 47:1-9

Ballirano P (2003) Effects of the choice of different ionization level for scattering curves and correction for small preferred orientation in Rietveld refinement: the $\mathrm{MgAl}_{2} \mathrm{O}_{4}$ test case. J Appl Crystallogr 36:1056-1061

Ballirano P, Maras A (2006) In-situ X-ray transmission powder diffraction study of the kinetics of the light induced alteration of realgar $\left(\alpha-\mathrm{As}_{4} \mathrm{~S}_{4}\right)$. Eur J Mineral 18:589-599
Ballirano P, Melis E (2007) Thermal behaviour of $\beta$-anhydrite $\mathrm{CaSO}_{4}$ to 1263 K. Phys Chem Miner 34:699-704

Ballirano P, Sadun C (2009) Thermal behavior of trehalose dihydrate $\left(T_{\mathrm{h}}\right)$ and $\beta$-anhydrous trehalose $\left(T_{\beta}\right)$ by in-situ laboratory parallelbeam X-ray powder diffraction. Struct Chem 20:815-823

Ballirano P, Pacella A (2020) Towards a detailed comprehension of the inertisation processes of amphibole asbestos: in situ high-temperature behaviour of fibrous tremolite. Mineral Mag 84:888-899

Berman RG (1988) Internally-consistent thermodynamic data for minerals in the system $\mathrm{Na}_{2} \mathrm{O}-\mathrm{K}_{2} \mathrm{O}-\mathrm{CaO}-\mathrm{MgO}-\mathrm{FeO}-\mathrm{Fe}_{2} \mathrm{O}_{3}-\mathrm{Al}_{2} \mathrm{O}_{3}-$ $\mathrm{SiO}_{2}-\mathrm{TiO}_{2}-\mathrm{H}_{2} \mathrm{O}-\mathrm{CO}_{2}$. J Petrol 29:445-522

Bosi F (2018) Tourmaline crystal chemistry. Am Mineral 103:298-306

Bosi F, Andreozzi GB, Federico M, Graziani G, Lucchesi S (2005) Crystal chemistry of the elbaite-schorl series. Am Mineral 90:1784-1792

Bosi F, Andreozzi GB, Skogby H, Lussier AJ, Abdu Y, Hawthorne FC (2013) Fluor-elbaite, $\mathrm{Na}\left(\mathrm{Li}_{1.5} \mathrm{Al}_{1.5}\right) \mathrm{Al}_{6}\left(\mathrm{Si}_{6} \mathrm{O}_{18}\right)\left(\mathrm{BO}_{3}\right)_{3}(\mathrm{OH})_{3} \mathrm{~F}$, a new mineral species of the tourmaline supergroup. Am Mineral 98:297-303

Bosi F, Naitza S, Skogby H, Secchi F, Conte AM, Cuccuru S, Hålenius U, De La Rosa N, Kristiansson P, Nilsson EJC, Ros L, Andreozzi GB (2018a) Late magmatic controls on the origin of schorlitic and foititic tourmalines from late-Variscan peraluminous granites of the Arbus pluton (SW Sardinia, Italy) crystal-chemical study and petrological constraints. Lithos 308:395-411

Bosi F, Skogby H, Hålenius U, Ciriotti M (2018b) Experimental cation redistribution in the tourmaline lucchesiite, $\mathrm{CaFe}^{2+}{ }_{3} \mathrm{Al}_{6}\left(\mathrm{Si}_{6} \mathrm{O}_{18}\right)$ $\left(\mathrm{BO}_{3}\right)_{3}(\mathrm{OH})_{3} \mathrm{O}$. Phys Chem Miner 45:621-632

Bosi F, Naitza S, Secchi F, Conte AM, Cuccuru S, Andreozzi GB, Skogby H, Hålenius U (2019a) Petrogenetic controls on the origin of tourmalinite veins from Mandrolisai igneous massif (Central Sardinia, Italy): Insights from tourmaline crystal chemistry. Lithos 342-343:333-344

Bosi F, Skogby H, Hålenius U (2019b) Thermally induced cation redistribution in fluor-elbaite and Fe-bearing tourmalines. Phys Chem Miner 46:371-383

Buick I, Grew ES, Armbruster T, Medenbach O, Yates MG, Bebout GE, Clarke GL (2008) Boromullite, $\mathrm{Al}_{9} \mathrm{BSi}_{2} \mathrm{O}_{19}$, a new mineral from granulite-facies metapelites, Mount Stafford, central Australia and a natural analogue of a synthetic "boron-mullite." Eur J Mineral 20:935-950

Bruker AXS (2016) Topas V6: general profile and structure analysis software for powder diffraction data. Bruker AXS, Karlsruhe

Cempírek J, Grew ES, Kampf AR, Ma C, Novák M, Gadas P, Škoda R, Vašinová-Galiová M, Pezzotta F, Groat LA, Krivovicev SV (2016) Vránaite, ideally $\mathrm{Al}_{16} \mathrm{~B}_{4} \mathrm{Si}_{4} \mathrm{O}_{38}$, a new mineral related to boralsilite, $\mathrm{Al}_{16} \mathrm{~B}_{6} \mathrm{Si}_{2} \mathrm{O}_{37}$, from the Manjaka pegmatite, Sahatany Valley, Madagascar. Am Mineral 101:2108-2117

Cheary RW, Coelho AA (1992) A fundamental parameters approach of X-ray line-profile fitting. J Appl Crystallogr 25:109-121

Dutrow B, Henry D (2011) Tourmaline: a geologic DVD. Elements 7:301-306

Federico M, Andreozzi GB, Lucchesi S, Graziani G, César-Mendes J (1998) Crystal chemistry of tourmalines. I. Chemistry, compositional variations and coupled substitutions in the pegmatite dikes of the Cruzeiro mine, Minas Gerais, Brazil. Can Mineral 36:415-431

Filip J, Bosi F, Novák M, Skogby H, Tuček J, Čuda WM (2012) Iron redox reactions in the tourmaline structure: high-temperature treatment of $\mathrm{Fe}^{3+}$-rich schorl. Geochim Cosmochim Acta 86:239-256

Fischer RX, Schneider H (2008) Crystal chemistry of borates and borosilicates with mullite-type structures: a review. Eur J Mineral 20:917-933 
Gonzalez-Platas J, Alvaro M, Nestola F, Angel R (2016) EosFit7-GUI: a new graphical user interface for equation of state calculations, analyses and teaching. J Appl Crystallogr 49:1377-1382

Henry DJ, Dutrow BL (1996) Metamorphic tourmaline and its petrologic applications. In: Grew ES, Anovitz LM (eds), Boron: mineralogy, petrology and geochemistry. Rev Miner Geochem 33:503-557

Henry DJ, Novák M, Hawthorne FC, Ertl A, Dutrow BL, Uher P, Pezzotta F (2011) Nomenclature of the tourmaline supergroup minerals. Am Mineral 96:895-913

Lührs H, Soellradl S, King SP, Hanna JV, Konzett J, Fischer RX (2014) Ambient and high-pressure synthesis, composition, and crystal structure of B-mullites. Cryst Res Tech 49:21-31

Lussier A, Ball NA, Hawthorne FC, Henry DJ, Shimizu R, Ogasawara Y, Ota $\mathrm{T}$ (2016) Maruyamaite, $\mathrm{K}\left(\mathrm{MgAl}_{2}\right)\left(\mathrm{Al}_{5} \mathrm{Mg}\right)$ $\mathrm{Si}_{6} \mathrm{O}_{18}\left(\mathrm{BO}_{3}\right)_{3}(\mathrm{OH})_{3} \mathrm{O}$, a potassium-dominant tourmaline from the ultrahigh-pressure Kokchetav massif, northern Kazakhstan: description and crystal structure. Am Mineral 101:355-361

Novák M, Cempírek J, Gadas P, Škoda R, Vašinová-Galiová M, Pezzotta F, Groat LA (2015) Boralsilite and Li, Be-bearing "boron mullite" $\mathrm{Al}_{8} \mathrm{~B}_{2} \mathrm{Si}_{2} \mathrm{O}_{19}$, breakdown products of spodumene from the Manjaka pegmatite, Sahatany Valley, Madagascar. Cam Mineral 53:357-374

Oberti R, Boiocchi M, Zema M, Hawthorne FC, Redhammer GJ, Susta U, Della Ventura G (2018) The high-temperature behaviour of riebeckite: expansivity, deprotonation, selective Fe oxidation and a novel cation disordering scheme for amphiboles. Eur J Mineral 30:437-449

Orlando A, Ruggieri G, Chiarantini L, Montegrossi G, Rimondi V (2017) Experimental investigation of biotite-rich schist reacting with B-bearing fluids at upper crustal conditions and correlated tourmaline formation. Minerals 7:155-177

Ota T, Kobayashi K, Katsura T, Nakamura E (2008a) Tourmaline breakdown in a pelitic system: implications for boron cycling through subduction zones. Contrib Mineral Petrol 155:19-32

Ota T, Kobayashi K, Kunihiro T, Nakamura E (2008b) Boron cycling by subducted lithosphere; insights from diamondiferous tourmaline from Kokchetav ultrahigh-pressure metamorphic belt. Geochim Cosmochim Acta 72:3531-3541

Pacella A, Tomatis M, Viti C, Bloise A, Arizza L, Ballirano P, Turci F (2020) Thermal inertization of amphiboles asbestos modulates Fe topochemistry and surface reactivity. J Hazard Mater 398:123119

Sabine TM, Hunter BA, Sabine WR, Ball CJ (1998) Analytical expressions for the transmission factor and peak shift in absorbing cylindrical specimens. J Appl Crystallogr 31:47-51

Shimizu R, Ogasawara Y (2013) Diversity of potassium-bearing tourmalines in diamondiferous Kokchetav UHP metamorphic rocks: a geochemical recorder from peak to retrograde metamorphic stages. J Asian Earth Sci 63:39-55

Werding G, Schreyer W (1992) Synthesis and stability of werdingite, a new phase in the system $\mathrm{MgO}-\mathrm{Al}_{2} \mathrm{O}_{3}-\mathrm{B}_{2} \mathrm{O}_{3}-\mathrm{SiO}_{2}$ (MABS), and another new phase in the ABS-system. Eur J Mineral 4:193-207

Young RA (1993) Introduction to the Rietveld method. In: Young RA (ed) the Rietveld method. Oxford University Press, Oxford, pp 1-38

Publisher's Note Springer Nature remains neutral with regard to jurisdictional claims in published maps and institutional affiliations. 